\title{
CENNIEJSZE NIŻ ZLOTO? METALE ZIEM RZADKICH W ŚWIATOWEJ STRATEGII GOSPODARCZEJ
}

Nie ulega wątpliwości, iż kontrola nad zasobami surowców energetycznych zwiększa możliwości oddziaływania na rzeczywistość międzynarodową i jest źródłem ogromnych zysków. Wraz z rozwojem nowoczesnych technologii wrosło zapotrzebowanie na innego rodzaju materiały niezbędne do ich wytwarzania. Dotyczy to przede wszystkim szczególnej grupy pierwiastków określanych jako metale ziem rzadkich (dalej: MZR). Stanowią one istotną część tablicy Mendelejewa i są wykorzystywane od soczewek okularowych, przez telefony komórkowe, a kończąc na samochodach. Ich szczególne właściwości dostrzegano już w XIX wieku. Jeden ówczesnych chemików sir William Brookes pisał, iż „w trakcie badań wprawiają nas w osłupienie, powodują konsternację, gdy chcemy na ich temat spekulować i strach, gdy zaczynamy snuć wokół nich marzenia" ". Mają one unikatowe właściwości chemiczne i fizyczne, które sprawiają, że efektem ich połączenia z innymi pierwiastkami są własności, których w żaden inny znany sposób nie można uzyskać. Tak szerokie ich zastosowanie sprawia, iż coraz częściej uznawane są za potencjalnie skuteczny element prowadzenia rozgrywek handlowych i politycznych na arenie międzynarodowej.

Zgodnie z „Amerykańskim Przeglądem Geologicznym” do MZR należą lantan i 14 lantanowców: cer, prazeodym, neodym, promet, samar, europ, gadolin, terb, dysproz, holm, erb, tul, iterb i lutet oraz skand i itr, które dodawane są do tej rodziny ze względu na podobne właściwości ${ }^{2}$. Dodatkowo podzielone są one na dwie podgrupy: lekkich i ciężkich metali ziem rzadkich. Do lekkich, które są częściej spotykane w przyrodzie, należą: lantan, cer, prazeodym, neodym i samar. Od czasu ich odkrycia w 1787 r. przez Carla Axela Arrheniusa w kamieniołomie Ytterby na jednej z wysp archipelagu sztokholmskiego cieszą się dużym zainteresowaniem naukowców i badaczy poszukujących kolejnych metod ich wykorzystania, zarówno do celów komercyjnych, jak i militarnych.

Obecnie związane są z każdym aspektem życia. Używane są między innymi do wytwarzania klisz rentgenowskich, katalizatorów redukcji spalin, fosforu do ekranów CRT, wysokoenergetycznych materiałów magnetycznych, laserów i wzmacniaczy optycznych ${ }^{3}$. Jednym z najlepszych przykładów są samochody. Na początku XX wieku

1 Cyt. za: J. Cipiur, Rzadka hossa na rzadkie metale, http://www.obserwatorfinansowy.pl/2011/06/22/surowce-metale-rzadkie-chiny (26.10.2011).

2 J. B. Hedrick, Rare-earth Metal Prices in the USA ca. 1960 to 1994, „Journal of Alloys and Compounds" 1997, nr 250, s. 471.

${ }_{3}$ M. Humphries, Rare Earth Elements: The Global Supply Chain, Congressional Research Service, http://www.fas.org/sgp/crs/natsec/R41347.pdf (28.10.2011). 
do ich produkcji używano zwykle pięciu surowców: drewna, kauczuku, stali, szkła i mosiądzu. W tej chwili według raportu National Academies, sporządzonego przez amerykańskich ekspertów doradzających w dziedzinie nauki i techniki, typowe auto może zawierać do 39 różnych minerałów w różnych kompozycjach, w tym także kilka metali mało znanych ${ }^{4}$. Bez metali ziem rzadkich nie moglibyśmy również korzystać z dobrodziejstw miniaturyzacji, a Internet byłby znacznie wolniejszy i mniej pojemny. Obrazuje to między innymi przykład samaru. W latach siedemdziesiątych ubiegłego stulecia konstruktorzy z firmy Sony zastosowali samar do produkcji magnesów montowanych w słuchawkach swego epokowego wynalazku - walkmana. Pierwiastek ten jest znacznie lżejszy od innych metali, z których można wytworzyć magnes trwały i jednocześnie utrzymuje silniejsze pole magnetyczne. Dziś w tej roli zastępuje go w telefonach jeszcze lżejszy i jeszcze bardziej „magnetyczny” neodym. Metale ziem rzadkich znajdują zastosowanie również w medycynie. Erb na przykład sprawia, że światło lasera medycznego jest w stanie usuwać defekty dermatologiczne czy stomatologiczne, ale nie pali przy tym skóry lub podniebienia pacjenta. W przypadku przemysłu militarnego MZR stosowane są do tworzenia systemów nawigacyjnych, radarów, sprzętu wykrywającego promieniowanie radioaktywne, zaawansowanych systemów komunikacji, a także broni i wyposażenia wojskowego ${ }^{5}$. Wykorzystywane są również w rolnictwie (głównie w ChRL), przede wszystkim do zwiększania wielkości zbiorów. Użycie MZR powoduje wzrost masy owoców, warzyw, czy też produkcji mleka czy jajek. Nadal jednak prowadzone są badania mające wyjaśnić wpływ metali ziem rzadkich na procesy wzrostu roślin i zwierząt ${ }^{6}$. Dodawane do „zwykłych” materiałów metale ziem rzadkich znacząco zwiększają ich potencjał i możliwości wykorzystania. Trudno jednak wskazać w tej grupie najbardziej potrzebny pierwiastek, ponieważ każdy z nich przyczynia się do utrzymania zrównoważonego tempa rozwoju cywilizacyjnego.

Powszechnie przyjęta i stosowana nazwa: metale ziem rzadkich, jest obecnie niewłaściwa. Metale te nie są bowiem na Ziemi rzadkie. W niskich stężeniach występują praktycznie wszędzie, w prawie każdej większej formacji skalnej. Zazwyczaj jednak stanowią część składową tlenków i węglanów, dlatego też przez tak długi okres nie zdawano sobie sprawy z ich obecności w przyrodzie. Niektóre, są równie powszechne jak metale podstawowe, na przykład nikiel czy metale szlachetne, takie jak złoto. Lantanu, odkrytego w 1893 r., występuje na Ziemi więcej niż srebra czy ołowiu. Problemem jest znalezienie złóż na tyle skupionych by ich eksploatacja była opłacalna. Kolejną kwestią, jak podkreśla profesor Tadeusz Łukasiewicz z Instytutu Technologii Materiałów Elektronicznych, jest ich niezastępowalność. „Charakteryzuje je bowiem określona struktura elektronowa, z czego wynikają takie, a nie inne własności decydujące z kolei

4 J. Blas, Rosna obawy o skape zasoby metali przejściowych i metali ziem rzadkich, http://forsal.pl/artykuly/395923,rosna_obawy_o_skape_zasoby_metali_przejsciowych_i_metali_ziem_rzadkich.html (27.10.2011).

5 L. Levkowitz, N. Beauchamp-Mustafaga, China's Rare Elements Industry and its Role in the International Market, http://www.uscc.gov/researchpapers/2011/RareEarthsBackgrounderFINAL.pdf (29.10.2011).

${ }_{6}$ Zob.: Rare Earth Elements in Agriculture with Emphasis on Animal Husbandry, red. W. A. Rambeck, Monachium 2006, http://edoc.ub.uni-muenchen.de/5936/1/Redling_Kerstin.pdf (27.12.2011). 
o własnościach wytwarzanych przyrządów i podzespołów. Albo mamy taką domieszkę i uzyskujemy odpowiedni efekt, albo jej nie mamy i nie ma tego efektu"”?

Ich produkcja znacznie różni się od wydobycia innych zasobów kopalnych. Największe problemy sprawia podobna budowa chemiczna tych pierwiastków. Ponadto rudy ziem rzadkich zawierają ślady substancji promieniotwórczych takich jak uran, tor, czy rad, co stwarza dodatkowe zagrożenie. Pierwszym z etapów pozyskiwania MZR jest wydobycie materiału przy zastosowaniu standardowych procedur górniczych. By wyodrębnić z rudy minerały mieli się ją na żwir, a następnie kilkukrotnie kruszy się do uzyskania drobnego piasku lub mułu, by oddzielić ziarna poszczególnych minerałów. Następnie rozdziela się pierwiastki w procesie filtracji, w którym metale przyczepiają się do bąbelków powietrza przepuszczanego przez zbiornik, w którym się znajdują. W efekcie metale można zebrać z jego powierzchni. Następnie przy użyciu różnorodnych chemikaliów uzyskuje się poszczególne metale ziem rzadkiech. Proces chemiczny powtarza się aż do uzyskania całkowitej czystości pierwiastków. Występują one wówczas w formie tlenków, które mogą być dalej przetwarzane w metale i stopy ${ }^{8}$.

Do 1948 r. najwięcej rzadkich metali wydobywano w Indiach i Brazylii. W latach pięćdziesiątych XX wieku prym wiodła Republika Południowej Afryki. Następnie czołowym producentem, aż do lat osiemdziesiątych XX wieku, była Kalifornia (znajdowała się tam największa na świecie kopalnia MZR w Mountain Pass). Obecnie metale nadal wydobywane są w kopalniach w Indiach i RPA, jednak nie może się to równać z produkcją chińską. W chińskiej prowincji Mongolia Wewnętrzna znajduje się największa na świecie kopalnia metali ziem rzadkich - Bayan Obo. W ChRL znajduje się obecnie 57\% światowych rezerw metali ziem rzadkich ${ }^{9}$. Jednocześnie ChRL kontroluje $97 \%$ rynku metali ziem rzadkich ${ }^{10}$. Jest to wynikiem subsydiowania ich produkcji przez chińskie władze w ciagu ostatnich dwóch dekad, a także wykładania znacznych środków na badania i rozwój w tym sektorze. W ten sposób pozbyto się konkurentów z rynku i uzyskano monopolistyczną pozycję. ChRL posiada przewagę w każdym z ogniw łańcucha ich dostarczania: wydobycia ród, oddzielania pierwiastków, rafinowania metali, tworzenia stopów i przetwarzania ich w komponenty produkcyjne ${ }^{11}$. Ponadto duży nacisk kładzie się na wykształcenie kadry inżynieryjnej przedsiębiorstw i naukowców poszukujących nowych zastosowań dla MZR. Studentów chińskich wysyła się głównie do Ames Laboratory funkcjonującego przy Departamencie Energii USA. Obecnie prawie $50 \%$ kończących tam studia pochodzi z $\mathrm{ChRL}^{12}$.

W jaki sposób supremacja ChRL w tej dziedzinie wpływa na kształt stosunków międzypaństwowych i wzrost chińskiej potęgi na arenie międzynarodowej? Konieczne jest

7 K. Kapiszewski, Lantanowce niczym ropa, „Przegląd” 2011, nr 2, http://www.przeglad-tygodnik.pl/pl/artykul/lantanowce-niczym-ropa (27.12.2011).

C. Hurst, China's Rare Earth Elements Industry: What Can the West Learn?, Washington 2010, http://fmso.leavenworth.army.mil/documents/rareearth.pdf (27.10.2011).

9 Dane za: G. Haxel, J. Hedrick, J. Orris, Rare earth elements critical resources for high technology, „United States Geological Survey” 2006, no 087-02, http://pubs.usgs.gov/fs/2002/fs087-02/ fs087-02.pdf (27.10.2011).

10 C. Hurst, op. cit.

11 Zob.: L. Levkowitz, op. cit.

12 C. Hurst, op. cit. 
spojrzenie na rozwój popytu na MZR w stosunku do podaży. Rozrost produkcji w sektorze elektronicznym, zielonych i nowoczesnych technologii motoryzacyjnych powoduje wzrost zapotrzebowania na te pierwiastki. Obecnie popyt na metale ziem rzadkich przewyższa podaż i nie wiadomo czy potencjalni producenci zdążą zwiększyć eksploatację zanim wyczerpią się ich zapasy. Dodatkowo wzrasta także zużycie MZR przez ChRL, co powoduje zmniejszenie nadwyżki surowca, który można by sprzedać na rynku międzynarodowym. Potwierdzeniem wzrastającego zapotrzebowania jest między innymi przyrost liczby użytkowników telefonów komórkowych (do których produkcji wykorzystuje się metale ziem rzadkich) z 600 milionów na koniec lipca 2008 roku do 670 milionów na koniec marca 2009 roku $^{13}$. Chińscy obywatele coraz chętniej kupują także inne urządzenia high-tech. Wedle różnych szacunków chińskie zużycie MZR przekroczy ich rezerwy pomiędzy 2012 a 2014 rokiem $^{14}$. Wzmożony popyt i gromadzenie zapasów przez chińskie przedsiębiorstwa popchnął ceny mocno w górę. W ciagu ostatnich pięciu lat wzrosły nawet trzykrotnie ${ }^{15}$. Ograniczony dostęp do pierwiastków powoduje bowiem, iż już same pogłoski o drobnych odchyleniach w podaży powodują kilkukrotny spadek lub wzrost cen. Na przykład wartość tlenku terbu używanego przy produkcji samochodów hybrydowych, czy systemach sonarowych, w ciagu trzech tygodni czerwca 2011 r. podskoczyła z 8750 do 20 tys. juanów za kilogram ${ }^{16}$.

W tej sytuacji chińskie władze uzyskują kolejne możliwości wpływania na kształt i rozwój wielu gałęzi przemysłu oraz zwiększania przychodów. Manipulacja podażą MZR ma między innymi zmusić zagraniczne firmy by otwierały tam fabryki. Kolejny powód, to ograniczenie produkcji baterii do samochodów hybrydowych, gdzie metale ziem rzadkich są niezbędne (w Chinach pracuje się obecnie nad prototypem tego typu pojazdu, który mógłby być sprzedawany na wielu rynkach zagranicznych). Na przykład produkowany przez Toyote - Prius zawiera około 10 funtów lantanu. Tworzone z niego akumulatory ocenia się na dwa razy bardziej wydajne niż te tradycyjne ${ }^{17}$. Do produkcji silnika używa się neodymu, prazeodymu, terbu, przy katalizatorach ceru. Metali rzadkich używa się nawet w szybach i lusterkach ${ }^{18}$. Prius stanowi około $8 \%$ całkowitej produkcji Toyoty. By utrzymać ją na takim poziomie korporacja ta (jako jedyny producent samochodów na świecie) inwestuje w kopalnie wydobywające metale ziem rzadkich.

Posiadany monopol na wydobycie tych surowców zaczął być wykorzystywany przez władze chińskie także do celów politycznych. Chodzi o stosowanie nieformalnego embargo, które według „New York Times” związane jest z zapowiedziami USA

13 China's Cell Phone Users Top 670 Mln, http://news.xinhuanet.com/english/2009-05/20/content 11404515.htm (28.12.2011).

${ }^{14}$ C. Hurst, op. cit.

15 Dane za: J. Blas, op. cit.

16 Dane za: L. Hook, Ceny metali ziem rzadkich wyjatkowo wysokie, bo Chiny gromadza zapasy, http://forsal.pl/artykuly/525291,ceny_metali_ziem_rzadkich_rekordowo_wysokie_bo_chiny_gromadza zapasy.html (28.10.2011).

${ }_{17}$ Dane za: M. Koerth-Baker, 4 Rare Earth Elements That Will Only Get More Important, http://www.popularmechanics.com/technology/engineering/news/important-rare-earth-elements\#fbIn$\operatorname{dex} 1(27.12 .2011)$.

${ }_{18}$ Zob.: J. Joyner, Hybrid Cars. Rare Earth Elements and Supply, http://www.outsidethebeltway.com/hybrid-cars-rare-earth-elements-and-supply/ (28.12.2011). 
odnośnie śledztwa $\mathrm{w}$ sprawie nielegalnych subwencji dla chińskich producentów urządzeń do wytwarzania zielonej energii (np. elektrowni wiatrowych) ${ }^{19}$. Dodatkowo część polityków w USA twierdzi, że w ten sposób chińskie władze chcą wyrugować amerykańskie firmy z szybko rozwijającego się rynku tych urządzeń i zapewnić tym samym miejsca pracy dla własnych robotników. Zyskać moga głównie na produkcji coraz częściej stosowanych turbin do elektrowni wiatrowych. Chiński sektor energii wiatrowej odnotowuje w ciagu ostatnich 5 lat znaczący wzrost. W ChRL pracuje już blisko 100 turbin wiatrowych.

Obawy ze strony USA nie są bezpodstawne. ChRL zdążyła już bowiem przejąć firmę Magnet-quench. Był to założony w 1986 r. odział General Motors, odpowiedzialny za magnesy oparte na neodymie, znajdujących zastosowanie w laserach w systemach namierzania celów, w komunikacji satelitarnej i systemach radarowych. Pierwsze działania w celu zakupu przedsiębiorstwa Chińczycy podjęli w $1995 \mathrm{r}$. Ostatecznie rząd Stanów Zjednoczonych zgodził się na transakcję pod jednym warunkiem: przez pięć lat firma miała funkcjonować na terytorium amerykańskim. Zastosowano jednak wybieg i skopiowano całą linię produkcyjną do Chin. Gdy upewniono się, że działa ona prawidłowo tę w Indianie zlikwidowano. W 2002 r., gdy pięcioletni termin zastrzeżony w umowie upłynął, całe wyposażenie wywieziono do ChRL. Mimo iż był to głównie sprzęt high-tech, zakład sprzedano za $70 \mathrm{mln}$ dolarów, a całej sprawie nie poświęcono wówczas zbyt wiele uwagi ${ }^{20}$.

Ofiarą chińskiego embargo padła również Japonia, która jest największym importerem MZR, między innymi za sprawą drugiej co do wielkości produkcji wysokich technologii na świecie. Zapotrzebowanie to nadal wzrasta, czego powodem jest japoński zwrot ku energii pochodzącej ze źródeł odnawialnych. Jest to element nowej polityki energetycznej państwa, szeroko popieranej przez społeczeństwo japońskie, które sceptycznie podchodzi do elektrowni jądrowych po ostatnich wydarzeniach w Fukushimie. Uzależnienie gospodarki Japonii od dostaw metali rzadkich ChRL wykorzystała we wrześniu 2010 r., gdy doszło do zderzenia chińskiego statku rybackiego z dwoma japońskimi okrętami patrolowymi. Miało to miejsce na Morzu Wschodniochińskim, w pobliżu wysp Senkaku, do których roszczenia zgłaszają oba państwa. Po incydencie wstrzymano chińskie dostawy metali ziem rzadkich do Japonii ${ }^{21}$, zaprzeczając jednocześnie, by ograniczenie eksportu do Japonii miało związek z incydentem. Według zapewnień chińskiego premiera Wen Jiabao, ChRL nie zamierza wykorzystywać metali rzadkich do zabiegów politycznych, jednakże są to tylko polityczne deklaracje, w które w rzeczywistości nikt nie wierzy. Z kolei chiński minister handlu - Chen Deming, zasugerował natomiast, iż eksporterzy chińscy mogli przystopować transporty z powodu swoich osobistych odczuć wobec Japonii. Sytuacja ta stanowi potwierdzenie pojawie-

19 K. Bradsher, China Said to Widen Its Embargo of Minerals, http://www.nytimes.com/2010/ 10/20/business/global/20rare.html?pagewanted=all (29.10.2011).

${ }_{20}$ Zob.: J. J. Tkacik Jr, How China Bought Magnequench, http://www.china-threat.com/how-china-bought-magnequench.html (28.12.2011).

21 Zapotrzebowanie Japonii na te metale wynosi rocznie około 30 tysięcy ton, a w roku 2010 otrzymała tylko połowę. Dane za: A. Kublik, Chiny straszq ograniczeniem dostaw metali ziem rzadkich, http://wyborcza.biz/biznes/1,101562,8550536,Chiny_strasza_ograniczeniem_dostaw_metali_ziem_rzadkich.html (29.10.2011). 
nia się w polityce na najwyższym szczeblu nowego rodzaju broni - rozgrywki surowcami - punktowego uderzenia w gospodarkę przeciwnika. Dodatkowo, jest to atak bez konieczności użycia ani jednej bomby, rakiety czy samolotu.

Chęć kontrolowania przez ChRL rynku metali ziem rzadkich, a przez to pośrednio także produkcji w ramach nowoczesnych technologii, może godzić w same Chiny. W grę wchodzi po pierwsze odwetowe embargo na dostawy do ChRL surowców, które są niezbędne dla podtrzymania rozwoju chińskiej gospodarki. Po drugie wzrost cen, ograniczenia w wydobyciu czy też blokowanie transportów coraz bardziej skłaniają inne państwa do poszukiwania opłacalnych w eksploatacji złóż i uruchamiania własnej produkcji. Z decyzją taką noszą się firmy amerykańskie, australijskie i rosyjskie. USA planują między innymi ponowne otwarcie należącej do Molycorp kopalni w Mountain Pass, zamkniętej w 2002 roku $^{22}$. Jednocześnie firma ta zapowiada zmianę technologii produkcji, tak by maksymalnie ograniczyć użycie szkodliwych chemikaliów, wykorzystywanych do oddzielenia metali ziem rzadkich od skał. Ponadto odpady chemiczne mają być recynklingowane i ponownie wykorzystywane. Według obliczeń Molycorp te unowocześnienia mają obniżyć cenę produkcji 1 kilograma czystych pierwiastków rzadkich do 2,77 dolara amerykańskiego ${ }^{23}$. Do wznowienia działalności w Mountain Pass dodatkowo zachęcają inne amerykańskie przedsiębiorstwa. Niektóre z kompanii chemicznych już zgłosiły Molycorp zapotrzebowanie na metale ziem rzadkiech. W. R. Grace, na przykład, oczekuje dużych dostaw ceru i lantanu, niezbędnych do produkcji katalizatorów używanych przy przetwarzaniu ropy naftowej w benzynę. Kolejnym znacznym odbiorcą metali ziem rzadkich w USA są przedsiębiorstwa Doliny Krzemowej. Surowiec ten jest tak istotny, iż pojawiły się nawet pogłoski, iż część z tamtejszych firm zaoferowało Molycorp pomoc finansową w zamian za gwarantowany procent z sumy wyprodukowanych $\mathrm{MZR}^{24}$. Działania te potwierdzają także zmianę w podejściu amerykańskich polityków do problemu. Coraz częściej pojawiają się bowiem pośród nich głosy, iż kwestia rodzimego wydobycia metali ziem rzadkich, jest sprawą narodowego bezpieczeństwa. Nie po raz pierwszy tego typu obawy powodują gromadzenie krytycznych zapasów. Podobna sytuacja zaistniała wcześniej w przypadku cyny, której rezerwy tworzono ze strachu, że komunizm rozleje się z Półwyspu Koreańskiego na ważnych jej producentów - Indonezję, Tajlandię i Malezję. W szczytowym momencie, czyli 1972 r., obejmowały one 250 tysięcy ton, co odpowiadało całej jej światowej podaży przez ponad rok. Rząd USA próbował się ich pozbyć przez następne 30 lat $^{25}$.

Z kolei Japończycy poinformowali o odkryciu potężnych złóż metali ziem rzadkich na dnie Oceanu Spokojnego. Znaleziono je w 78 miejscach, na wodach międzynarodowych, na wschód i na zachód od Hawajów oraz na wschód od Tahiti. Według zespołu profesora Yasuhiro Kato z Uniwersytetu Tokijskiego 1 kilometr kwadratowy osadów $\mathrm{z}$ dna może zaspokoić $20 \%$ obecnego zapotrzebowania na te metale ${ }^{26}$. Problemem bę-

${ }^{22}$ Molycorp.Inc, http://www.molycorp.com/Home.aspx (31.10.2011).

23 Dane za: T. D'Altorio, Molycorp's Domestic Rare Earth Production About to Get Underway, http://www.investmentu.com/2011/July/molycorp-rare-earth-domestic-production.html (31.10.2011).

24 Ibidem.

25 J. Blas, op. cit.

${ }^{26}$ M. Błoński, Odkryto kolosalne złoża metali ziem rzadkich, http://kopalniawiedzy.pl/metale-ziem-rzadkich-zloza-Ocean-Spokojny-13392.html (30.10.2011). 
dzie jednak wydobycie cennego materiału na powierzchnię. Znajduje się on bowiem od 3500 do 6000 metrów pod poziomem wody. Nie wiadomo więc czy inwestycja będzie opłacalna i w jaki sposób może wpłynąć na stan środowiska naturalnego. Firmy działają również na rzecz zróżnicowania dostawców. Toyota Tsusho (spółka zależna japońskiego producenta samochodów) w styczniu 2010 roku zawarła z australijską firmą Orocobre umowę, która ma na celu pomoc w eksploatacji złóż litu w Argentynie $^{27}$. Działania te są częścią ogłoszonej w 2009 roku ,Strategii dla zapewnienia stabilnych dostaw metali rzadkich”. Jej realizacją zajmują się Ministerstwo Gospodarki, Handlu i Przemysłu, JOGMEC, czyli Narodowa Japońska Korporacja Paliw, Gazu i Metali oraz Bank Międzynarodowej Kooperacji Japonii. Ponadto rząd oferuje wsparcie dyplomatyczne dla przedsiębiorstw poszukujących innych źródeł dostaw.

Wsparcia przedsiębiorcom udziela również rząd Korei Południowej. Podobnie jak w Japonii znaczna część jej produkcji przemysłowej opiera się na wykorzystaniu metali ziem rzadkich. W ramach „Programu Stabilnego Pozyskiwania Metali Rzadkich” planuje się wydanie do 2016 r. 15 milionów dolarów na zgromadzenie 1200 ton metali i wspomożenie własnych kopalni. Przedsiębiorstwa państwowe planują również inwestowanie w kopalnie litu, uranu, niklu w Afryce i Ameryce Łacińskiej. Ponadto nacisk kładzie się na poszukiwanie materiałów zastępczych, zwiększenie efektywności produkcji oraz recykling opadów pochodzących z różnych faz produkcji ${ }^{28}$.

Alternatywnych dostawców poszukują również przedsiębiorstwa europejskie, między innymi Continental (niemiecki producent opon, który kupuje silniki elektryczne i części silników zawierające metale ziem rzadkich niezbędne do produkcji materiałów magnetycznych) i Bosh (największy na świecie producent części samochodowych). Sprawdzają one zagrożenia mogące wyniknąć z prowadzonej przez władze w Pekinie polityki eksportowej. Podobne działania podjął również Siemens. Sytuację uznano za na tyle poważną, iż Europejskie Stowarzyszenie Dostawców Branży Motoryzacyjnej (European Association of Automotive Suppliers - CLEPA), reprezentujące 3 tysiące firm, zwróciło się w 2010 r. do Komisji Europejskiej z wnioskiem o szukanie możliwości zapewnienia dostaw metali ziem rzadkich ${ }^{29}$. Komisja ogłosiła, iż MZR należą do grupy surowców, w przypadku których przestoje w zaopatrzeniu mogą doprowadzić do sytuacji krytycznej w europejskim przemyśle. Oprócz metali ziem rzadkich wymieniono również importowane platynowce. Lista „surowców krytycznych” ma być aktualizowana co trzy lata ${ }^{30}$.

Działania na szerszą skalę Unia Europejska podjęła w 2011 r. Szansy, obok gromadzenia zapasów MZR, upatruje się w bardziej racjonalnym ich wykorzystaniu oraz recyklingu. Oprócz możliwości ponownego użycia materiałów, sektor recyklingu daje

27 Zob.: ASX Announcement and Media Release. $20^{\text {th }}$ January 2010. Orocobre and Toyota Tsusho Announce JV to Develop Argentine Lithium Project, Orocobre, http://www.orocobre.com.au/PDF/ ASX_20Jan10_Orocobre\%20and\%20Toyota\%20Tsusho\%20Announce\%20JV.pdf (31.10.2011).

${ }^{28}$ Critical Material Strategy, U.S. Department of Energy, Washington 2010, http://www.energy.gov (15.12.2011).

29 O. Kinnader, C. Rahn, Problemy $z$ dostępem do metali ziem rzadkich, http://m.onet.pl/biznes/3764249, detal.html (2.11.2011).

${ }^{30}$ Siegamy po nowe rozwiazania, ,Rzeczpospolita”, 16.09.2011, http://www.min-pan.krakow.pl/ pbs/konferencja/dodatek.pdf (2.11.2011), s. 2. 
także nowe miejsca pracy i ma duży potencjał w kwestii ochrony klimatu. Europosłowie domagają się również od Komisji Europejskiej przedstawienia wyraźnych celów wykorzystania MZR na wzór japoński oraz wprowadzenia jednolitej strategii dotyczącej surowców naturalnych, lepszego monitorowania rozwoju rynku, zwiększenia wydobycia surowców w ramach Unii Europejskiej, międzynarodowego certyfikowania państwa pochodzenia i aktywnej „,dyplomacji surowcowej” w różnych dziedzinach, takich jak polityka zagraniczna, handlowa, środowiskowa i rozwojowa ${ }^{31}$. Rekomendacje Parlamentu Europejskiego za użyteczne uznał komisarz do spraw Przemysłu Antonio Tajani. Zasugerował ponadto, by starać się zawiązywać podobne porozumienia odnośnie ziem rzadkich, jakie UE zawarła do tej pory z USA, Japonią, Chile i Unią Afrykańską. Planuje się również zawiązanie długoterminowej współpracy z bogatą w metale rzadkie Grenlandią ${ }^{32}$.

Wedle Reinharda Bütikofera ${ }^{33}$, sprawozdawcy i zastępcy przewodniczącego frakcji Zielonych w PE, Unia „powinna prowadzić innowacyjną strategię, bazującą na efektywności surowcowej i ponownym wykorzystaniu surowców naturalnych, aby w ten sposób wspierać trwałość i konkurencyjność gospodarki. Europa musi sobie przy tym stawiać ambitne cele. Decydująca jest przy tym dobra współpraca między Unią Europejską a państwami członkowskimi”" ${ }^{\text {"3 }}$. Ponadto zasugerował utworzenie elitarnej instytucji, która zajmowałaby się pozyskiwaniem dla unijnego przemysłu rzadkich rud. W skład takiej struktury wchodziłyby instytuty badawcze, firmy, politycy oraz organizacje pozarządowe. W Europie kwestią rzadkich metali zajmują się m.in. niemieckie Bundesanstalt für Geowissenschaften und Rohstoffe i Fraunhofer-Gesellschaft, które miałyby wejść w skład tworzonego przez UE zespołu. Jego zadaniem, zdaniem R. Butikofera, miałoby być odpowiedzenie do 2013 r. na 5 zasadniczych pytań: w których sferach UE może polepszyć swe prace badawcze; jak wdrożyć recykling rzadkich metali, by mogły one ponownie być stosowane w produkcji; gdzie brakuje patentów; w jaki sposób Europejski Bank Inwestycyjny może pomóc unijnym przedsiębiorcom; gdzie opłaca się wydobywać rzadkie metale ${ }^{35}$. Deputowany wnioskował o milion euro na przeprowadzenie studium w 2012 r. Podobne ekspertyzy, do tych proponowanych przez europosła, zostały już przeprowadzone w RFN, na użytek ich rodzimej gospodarki. Wynika z nich, że już teraz niezbędne jest przygotowanie instytucji państwa i gospodarki do sytuacji niedoboru surowców naturalnych, przy czym szczególną uwagę zwraca się na krótki czas, jaki pozostał do podjęcia odpowiednich decyzji. Jednocze-

31 Zabezpieczenie dostaw metali ziem rzadkich dla Europy (debata), Parlament Europejski, http://www.europarl.europa.eu/sides/getDoc.do?pubRef=-//EP//TEXT+CRE+20110308+ITEM-019+ $\mathrm{DOC}+\mathrm{XML}+\mathrm{V} 0 / / \mathrm{PL}(2.11 .2011)$.

32 European Parliament calls for greater EU clout over raw materials, CLEPA, http://www.clepa.eu/news/view/article/european-parliament-calls-for-greater-eu-clout-over-raw-materials/ (2.11.2011).

33 Wypowiedź i działania tego niemieckiego polityka potwierdzają ogromne znaczenie, jakie Niemcy przywiązują do strategii pozyskiwania metali ziem rzadkich, tak istotnych dla rozwoju ich gospodarki.

${ }^{34}$ Cyt. za: Europejska strategia dotyczaca surowców naturalnych, http://www.wzp.pl/westpomerania/p-r-m-a-13826/aktualnosci_z_brukseli.htm (2.11.2011).

${ }_{35}$ M. Wieroński, Jak UE zamierza pozyskiwać metale rzadkie, http://ebe.org.pl/przeglad-prasy/jak-ue-zamierza-pozyskiwac-rzadkie-metale.html (28.12.2011). 
śnie zaznaczono, iż gospodarki nowych, słabiej rozwiniętych państw członkowskich UE mogą nie sprostać ewentualnemu deficytowi lub całkowitemu zastopowaniu dostaw tych surowców.

Obok wspólnych działań w ramach UE, poszczególne państwa członkowskie dodatkowo rozwijają własną politykę zabezpieczania dostaw metali ziem rzadkich. W Holandii na przykład planuje się wprowadzenie szerokiej współpracy pomiędzy rządem, ośrodkami naukowymi i przemysłem. Po pierwsze, mają zostać przeprowadzone badania wzorców zużycia metali w celu ich bardziej racjonalnego wykorzystania w przyszłości. Ma zostać również zwiększona ilość materiałów kierowanych do recyklingu ${ }^{36}$. W Niemczech najwięcej głosów odnośnie zmiany polityki dostaw MZR płynie od samych przedsiębiorców. Zrzeszenie niemieckich przemysłowców na zorganizowanym w Berlinie w październiku 2010 r. III Kongresie Surowcowym lobbowało za aktywniejszym udziałem polityków w rozwiązywaniu problemów gospodarki surowcami w RFN. Producenci konstatowali, że bezpieczny dostęp do surowców jest kluczowym czynnikiem sukcesu ich rodzimego przemysłu i postulowali opracowanie spójnej strategii surowcowej Niemiec i UE. Szczególnie interesujące w tym kontekście było wystąpienie ministra gospodarki Rainera Brüderle, który obiecał przemysłowcom wsparcie, głównie w formie poręczeń w obrocie handlowym; a także większe zaangażowanie Izb Handlu Zagranicznego oraz agencji federalnej Germany Trade and Invest w monitorowaniu i analizowaniu trendów rynkowych w tej dziedzinie. Jednocześnie minister przypomniał przedsiębiorcom, iż odpowiedzialność za zabezpieczanie dostępu do surowców nadal spoczywa na barkach firm, a rząd nie będzie angażować się w negocjacje warunków kontraktów handlowych. Nie będzie też posiadał udziałów w spółkach powołanych przez przemysł w celu pozyskiwania surowców. Taką samą wykładnię zastosowała kanclerz Angela Merkel, w trakcie kryzysu wywołanego przez wstrzymanie przez ChRL dostaw metali ziem rzadkich ${ }^{37}$. Retoryka taka oznacza, iż władze Niemiec chcą wspierać rodzimy przemysł, ale tylko w takim zakresie, w jakim nie wpłynie to negatywnie na relacje $\mathrm{z}$ władzami w Pekinie.

Problemy na rynku powodują również wzrost nakładów na badania i rozwój, aby ograniczyć wykorzystanie metali ziem rzadkich w nowoczesnych technologiach lub całkowicie je wyeliminować. Zalecenie takie znalazło się między innymi w rządowym dokumencie USA „Critical Materiale Strategy” z grudnia 2010 r. Poszukuje się również surowców alternatywnych. Badania nad substytutami MZR w USA finansuje Agencja Zaawansowanych Projektów Badawczych dla Energii (Advanced Research Projects Agency for Energy - ARPA-E). Prowadzone są one między innymi na uniwersytetach w Nebrasce i Delaware ${ }^{38}$. Wraca się również do dawnych wynalazków, na przykład indukcyjnego silnika elektrycznego Nikoli Tesli. Jednakże tego typu silniki nadal są znacznie większe i cięższe niż te, w których stosuje się metale rzadkie.

${ }^{36}$ Critical Materiale Strategy, U.S. Departament of Energy, http://energy.gov/sites/prod/files/edg/news/documents/criticalmaterialsstrategy.pdf (31.10.2011).

37 A. Kwiatkowska-Drożdż, Deficyt surowców naturalnych-implikacje dla niemieckiej polityki, http://www.osw.waw.pl/pl/publikacje/komentarze-osw/2011-02-08/deficyt-surowcow-naturalnych-implikacje-dla-niemieckiej-polityk (29.12.2011).

38 Zob.: Critical Materiale Strategy, op. cit. 
Z kolei chińskie władze twierdzą, iż ich polityka odnośnie MZR nie ma na celu ograniczania wzrostu technologicznego. Jak stwierdziła w 2009 roku Wang Caifang, zastępczyni dyrektora generalnego w Ministerstwie Przemysłu: „Wszystkie nasze decyzje będą spójne z rozwojem nauki. Chiny się nie zamkną" ${ }^{39}$. Takie zapewnienia nie uspokajają jednak przedsiębiorców i polityków na Zachodzie.

Ograniczenia $\mathrm{w}$ dostawach sprawiają, iż popyt na chiński surowiec stopniowo zmniejsza się. Dodatkowo do spadku cen w ostatnich miesiącach doprowadziły także fale spekulacji. Jak podała firma Shanghai Metals Market, która zbiera i przetwarza informacje na potrzeby rynków metali nieżelaznych, zmniejszyły się one aż o 20 procent $^{40}$. W tej sytuacji największy chiński wytwórca tych pierwiastków spółka Baotou Steel Rare-Earth, w październiku 2011 r. podjęła decyzję o wstrzymaniu produkcji na miesiąc. Rząd Chin ustalił górną granicę rocznej produkcji MZR na 93 tys. ton, natomiast limit ich eksportu na 30194 ton, nieco mniej niż w roku 2010, kiedy wynosił on 30258 ton $^{41} .27$ grudnia $2011 \mathrm{r}$. chińskie władze poinformowały, iż na pierwszą połowę 2012 r. limit eksportowy wyznaczono na 10546 ton. Jest to o $27 \%$ mniej, niż w analogicznym okresie 2011 roku $^{42}$. Ma to służyć ograniczeniu dalszego spadku cen na MZR. Zachowania te już wcześniej wywołały reakcję Światowej Organizacji Handlu (WTO), której przedstawiciele w lipcu 2011 r. skrytykowali ChRL za ograniczenie eksportu rzadkich pierwiastków. Skargę w 2009 r. złożyły władze UE, USA i Meksyku. Organizacja zarzuciła, iż są to działania sprzeczne z zasadami, do przestrzegania których ChRL zobowiązała się przystępując do WTO. Jednocześnie odrzucono thumaczenie rządu chińskiego, że limity mają się przysłużyć ochronie środowiska naturalnego ${ }^{43}$. Taki obrót spraw cieszy należącą do Molycorp, estońską firmę Slimet, zajmującą się wydobyciem metali ziem rzadkich $^{44}$. Jest to mały producent, zaopatrujący około 15 firm ze Stanów Zjednoczonych, Unii Europejskiej i Rosji. W ciągu roku, cena sprzedawanego przez Slimet ceru, używanego przy produkcji szkła, wzrosła o $1000 \%$ - z 3,50 do 40,00 dolarów za kilogram ${ }^{45}$.

W jakim położeniu znajdzie się więc ChRL? Czy strategia ograniczania produkcji i wprowadzania limitów eksportowych uczyni z nich głównego rozgrywającego na rynku metali ziem rzadkich? Słuszne staje się stwierdzenie z 1992 r. ówczesnego

39 Cyt. za: J. Blas, op. cit.

40 Metale ziem rzadkich: Chiny ograniczaja wydobycie by utrzymać wysokie ceny, http://forsal.pl/artykuly/558298,metale_ziem_rzadkich_chiny_ograniczaja_wydobycie_by_utrzymac_wysokie ceny.html (29.10.2011).

${ }_{41}$ Dane za: Chiny: miesiac przerwy największego producenta metali ziem rzadkich, http://hutnictwo.wnp.pl/chiny-miesiac-przerwy-najwiekszego-producenta-metali-ziem-rzadkich,153373_1_0_0.html (29.10.2011).

${ }_{42}$ Chiny ograniczaja eksport metali ziem rzadkich, http://forsal.pl/artykuly/579079, chiny_ograniczaja_eksport_metali_ziem_rzadkich.html (28.12.2011).

${ }_{43}$ China Keeps Rare Earth Supllies Tight Despite WTO Warning, http://seekingalpha.com/article/279670-china-keeps-rare-earth-supplies-tight-despite-wto-warning (31.10.2011).

44 Zob.: J. Lifton, Why did Molycorp Buy Slimet \% Was it Worht the Money?, http://www.resourceinvestor.com/News/2011/4/Pages/Why-Did-Molycorp-Buy-Silmet-and-Was-it-Worth-the-Money.aspx (31.10.2011).

45 China Rare Earth Spat helps Estonia firm..., http://www.silmet.ee/default.aspx?m1=44\&id= 174\&lang=1 (31.10.2011). 
przywódcy Deng Xiaoping'a: „Metale ziem rzadkich to dla Chin coś takiego jak ropa dla Bliskiego Wschodu. Jest to kwestia o znaczeniu strategicznym. Musimy mieć pewność, że zajmiemy się nią w odpowiedni sposób i wykorzystamy przewagę naszego kraju w metalach ziem rzadkich" ${ }^{\text {,6 }}$. Obecnie Chiny odnoszą znaczące korzyści posiadając monopol na dystrybucję MZR. Tak jak zakładano, zagraniczne firmy przenoszą część swoich produkcji na ich terytorium. Jednakże tak samo jak poszukuje się alternatywnych źródeł energii, by uniezależnić się od dostaw ropy i gazu, bada się materiały mogące stanowić substytuty dla metali ziem rzadkich. W sytuacji, gdy inne państwa poważnie zastanawiają się nad wznowieniem własnego wydobycia, władze ChRL powinny skupić się na wykorzystaniu własnych rezerw rzadkich pierwiastków do rozwinięcia w jak najszerszym zakresie sektorów nowoczesnych i zielonych technologii. W sytuacji, gdy popyt na chińskie surowce spadnie, ich gospodarka będzie nadal posiadać silną kartę przetargową.

Ponadto nie można zapomnieć o ochronie środowiska naturalnego. Ze strony ChRL już podejmowane są działania zmierzające do likwidacji niebezpiecznych i zanieczyszczających środowisko kopalni wszystkich surowców. Ma to na celu wprowadzenie „trwałego i zdrowego rozwoju” w tym sektorze. Paradoksalnie wydobywanie metali ziem rzadkich, tak istotnych dla ,zielonych technologii”, jest potencjalnie rujnujące dla środowiska ${ }^{47}$. Zgodnie z danymi publikowanymi przez Chińskie Stowarzyszenie Ziem Rzadkich na każdą wyprodukowaną tonę metali rzadkich przypada 8,5 kilograma fluoru i 13 kilogramów pyłów. Nieodpowiednio oczyszczana przez zakłady woda zatruwa środowisko naturalne ${ }^{48}$. Ruda transportowana jest $\mathrm{w}$ otwartych wagonach, a część z niej trafia do Żółtej Rzeki i dalej do Morza Żółtego. Nie stosuje się również procedur ochrony ludności pracującej przy wydobyciu przed promieniowaniem radioaktywnym i zanieczyszczeniami. Wzrasta liczba osób chorujących na raka i choroby płuc. By zredukować te zjawiska ChRL musi przebyć jeszcze długą drogę. Bowiem, gdy jedne firmy zwiększają nakłady na czyste technologie, inne poszukują maksymalnych oszczędności by utrzymać się na rynku, a rząd nie udziela żadnej finansowej pomocy na wyrównanie przez chińskie przedsiębiorstwa do międzynarodowych standardów.

Walczyć należy także z nielegalnym wydobyciem i przemytem surowców. Powoduje on wahania cenowe i szybsze wyczerpanie rud. Ogranicza również kontrolę władz nad przemysłem wydobywczym i może prowadzić do dalszego zniszczenia środowiska. Wedle szacunków China Business News w 2008 r. nielegalnie wywieziono z kraju około 20 tysięcy ton MZR. Oficjalne statystyki celne z tego samego roku podają, iż ChRL eksportowała 39500 ton surowca ${ }^{49}$. Oznacza to, iż ilość towaru przemycanego osiagała jedną trzecią zasobów sprzedawanych legalnie. $Z$ tego powodu wprowadzono specjalny program zmian w perspektywie lat 2009-2015. Jednakże ze względu na słabo rozwinięte praktyki zarządzania i ogrom branży wprowadzenie jakichkolwiek regulacji jest utrudnione.

46 Cyt. za: M. Błoński, op. cit.

47 J. Blas, op. cit.

48 C. Hurst, op. cit.

49 Dane za: China mulls plans to curb rare earth smuggling, http://www.chinadaily.com.cn/bizchina/2009-09/14/content_8690293.htm (20.12.2011). 
Przed państwami zachodnimi staje zatem wiele zadań. Po pierwsze, uniezależnić się od dostaw chińskich. Nie jest to możliwe bez lepszego zrozumienia łańcucha dostaw oraz wyeliminowania $\mathrm{z}$ niego wszystkich zbędnych, podwyższających koszty elementów. Inne natomiast zastąpić substytutami (co nie jest możliwe bez podniesienia nakładów na badania i rozwój). Rozwinąć należy system recyklingu. Do tej pory taniej było kupić nowy sprzęt z ChRL, która „elektrośmieci” przetapiała dla odzyskania cennego materiału. Jak twierdzi profesor Mirosław Rutkowski: „te minerały nie mają metryki. Część z nich musi pochodzić z brudnego recyklingu. Teraz urban mining (górnictwo miejskie), bo tak mówi się na proces odzyskiwania minerałów z niechcianych produktów, zacznie się opłacać i u nas" ${ }^{90}$. Należy dążyć do wznowienia wydobycia w zamkniętych kopalniach, na przykład Mountain Pass.

Żadne z tych działań nie przyniosą jednakże skutków, jeżeli handel metalami ziem rzadkich będzie wykorzystywany do prowadzenia rozgrywek politycznych i jako argument w negocjacjach. Jak stwierdził były szef Międzynarodowego Funduszu Walutowego Dominique Strauss-Kahn (mówiąc o Chinach) „nie można jednocześnie być w centrum, a zachowywać się jak pasażer na gape ${ }^{\text {"51 }}$. Wszystkim potrzebna jest rozwaga i odpowiedzialność, a granie surowcami nie jest ani odpowiedzialne, ani rozsądne, ani korzystne.

\section{STRESZCZENIE}

Obecnie dla rozwoju gospodarczego istotne znaczenie, obok ropy i gazu ziemnego, zyskuja metale ziem rzadkich. Bez ich zastosowania wiele $\mathrm{z}$ wynalazków nowoczesnych technologii wyglądałoby zupełnie inaczej, a inne wcale by nie istniały. Metale ziem rzadkich są bowiem kluczowym komponentem zaawansowanych urządzeń wojskowych i cywilnych, a także kluczowym elementem w stosowaniu zielonych technologii takich jak turbiny wiatrowe czy samochody hybrydowe. Do grupy metali ziem rzadkich należy 17 pierwiastków, które w umiarkowanych ilościach znajdują się w skorupie ziemskiej. Pomimo swojej nazwy, zasoby niektórych z nich są większe niż miedzi, ołowiu, złota czy platyny. Niestety nie występują w dużych skupiskach, co znacznie utrudnia i podraża ich eksploatację. 97 procent metali ziem rzadkich produkowane jest obecnie w ChRL. Jednakże rosnące światowe zapotrzebowanie, jak i chińskie ograniczenia eksportowe w ciągu ostatnich sześciu lat rodzą obawy międzynarodowych koncernów co do utrzymania ciągłości dostaw. Sytuację dodatkowo utrudnia wzrastający popyt wewnętrzny ChRL. Nawet te państwa, które w znacznym stopniu zaspokajały zapotrzebowanie na metale rzadkie z własnych zasobów, w ciagu ostatniej dekady uzależniły się od zaopatrzenia chińskiego. Sytuacja taka wywołuje niepokój, co do wykorzystania przez ChRL monopolu do realizacji celów politycznych. Biorąc pod uwagę wstrzymywanie dostaw do Japonii, obawy te nie wydają się nieuzasadnione.

Poniższe opracowanie ma na celu ukazanie potencjału gospodarczego metali ziem rzadkich, sposobów ich wykorzystania i znaczenia dla współczesnej gospodarki. Wskazuje także możliwe drogi stawienia czoła chińskiemu monopolowi przez inne państwa.

${ }^{50}$ Cyt. za: K. Kapiszewski, op. cit.

51 Cyt. za: P. Wołejko, Wojny surowcowe, http://www.politykaglobalna.pl/2010/10/wojny-surowcowe/ (28.12.2011). 


\title{
MORE VALUABLE THAN GOLD? \\ RARE EARTH ELEMENTS IN GLOBAL ECONOMIC STRATEGY
}

\begin{abstract}
Next to oil and gas there are which have increasing importance for industrial development - rare earth elements. Without them, much of the world's modern technology would be vastly different and many applications would not be possible. They are key component of in a large assortment of advanced military and civilian technologies and key to the emergence of green technology such as the new generation of wind powered turbines and plug-in hybrid vehicles. There are 17 rare earth elements which moderately are abundant in the earth's crust, some even more abundant than copper, lead, gold, and platinum. Although they are not concentrated enough to make them easily exploitable economically. 97 percent of the world's rare earth elements are produced in China. Increasing global demand and Chinese reductions in export quotas over the past six years have led to international concerns about future supply shortages. China's request for rare earths is also growing, what causes even more problems for importers of these resources. Even those countries which were largely self-sufficient in these critical materials over the past decade have become dependent upon imports from Beijing. In addition, this monopoly over rare earths has led to fears of China using its dominance as leverage to influence other nations' foreign policies. Considering example of Japan, these anxieties are not groundless.

This paper is designed to present te phenomenon of rare earth elements and their importance for international economy. It also explores ways of facing Chinese monopoly by other states.
\end{abstract}


